\title{
Tata Laksana Pemeliharaan Ayam Cemani Di Peternakan NF Temanggung Jawa Tengah
}

\section{Rearing Management Cemani Chicken in NF Farm, Temanggung, Jawa Tengah}

\author{
I K Habsari ${ }^{*}$, B A Nugroho ${ }^{1}$, dan S Azizah ${ }^{1}$ \\ ${ }^{1}$ University of Brawijaya, Jln Veteran, Malang, Jawa Timur \\ *E-mail korespondensi: intankhabsari@gmail.com
}

\begin{abstract}
This study was aimed to observe rearing management of cemani chicken in NF Farm, Temanggung, Central Java. NF Farms was chosen purposively due to the high population. Data collection techniques using observation techniques, direct observation of maintenance management which includes cage and chicken feed cemani. The result showed that Cemani chickens in grower period used battery cage $120 \times 60 \mathrm{~cm}^{2}$ for 2-3 chickens in each cage, while in layer period used litter cage $6 \times 4 \mathrm{~m}^{2}$ and each cage consisted of 1 male and 5 female cemani chicken. Feeding management NF farm for 1-3 days old were only given drinking water added by palm sugar. 3- 40 days old Cemani chickens were fed 511 given 25-30 g/bird/day with $22 \%$ protein content and 3,050 kkal/kg energy. Whereas for the grower period feed is divided into two, at the age of 41-75 days, chickens are fed with BR 1 and corn ratio 1:1, and for 76 days- 6 months old, they are fed with ground corn, bran and BR 1 with the ratio 1: $1: 1$ as much as $80 \mathrm{~g} / \mathrm{head} /$ day.
\end{abstract}

Keywords: Cemani, Rearing management, Feeding

Diterima: Disetujui:

\section{PENDAHULUAN}

Ayam Kedu merupakan salah satu ayam lokal yang mempunyai karakteristik tertentu dan berasal dari daerah Karesidenan Kedu - Jawa Tengah terutama di Kabupaten Temanggung. Ayam Kedu yang masih banyak dijumpai adalah ayam Kedu hitam yang mempunyai karakteristik spesifik ditandai dengan seluruh warna bulunya yang hitam, bahkan ada seluruh tubuhnya dari kulit, daging, tulang, paruh, kloaka, jengger, muka, kaki berwarna hitam, ayam Kedu ini dikenal dengan sebutan ayam "Cemani". Ayam cemani memiliki value yang tinggi namun sistem pemeliharaan yang belum terlalu dikenal oleh masyarakat. Oleh karena itu pengamatan ini bertujuan untuk mengetahui pemeliharaan ayam cemani meliputi manajemen kandang dan pakan.

\section{MATERI DAN METODE}

Penelitian dilaksanakan di peternakan ayam cemani NF, Desa Beji, Kedu, Temanggung, Jawa Tengah. Pemilihan lokasi dilakukan secara sengaja (Purposive) berdasarkan pertimbangan bahwa pusat peternakan ayam cemani di Indonesia berada di Desa Beji, Kedu, Temanggung, Jawa Tengah. Teknik pengambilan data menggunakan teknik observasi, pengamatan langsung mengenai manajemen pemeliharaan yang meliputi kandang dan pakan ayam cemani. Data yang didapat dianalisis menggunakan analisis deskriptif. 


\section{HASIL DAN PEMBAHASAN}

\section{Aspek Produksi}

Pemeliharaan ayam cemani pada dasarnya sama dengan pemeliharaan ayam kampung. Sebagian besar ayam cemani yang ada di Temanggung bertujuan untuk dipelihara sebagai ayam hias dan ada juga yang dipelihara untuk menghasilkan telur yang nantinya ditetaskan sebagai bibit atau regenerasi. Ben Dorshorst (2012) mengungkapkan penyebab dari warna hitam yang dimiliki ayam Cemani. Tubuh ayam Cemani yang berwarna hitam merupakan hasil mutasi genetik berupa duplikasi pada area genom yang terdiri dari 5 gen, sehingga terjadilah fibromelanosis atau hiperpigmentasi. Salah satu gen yang terdapat pada area duplikasi tersebut adalah Endothelin 3 (EDN3) yang berperan dalam pembentukan protein penghasil melanosit. Hal ini menyebabkan ekspresi berlebih protein pembentuk melanosit pada saat ayam Cemani masih berupa embrio. Hasilnya, ayam Cemani memiliki tubuh bahkan organ tubuh yang berwarna hitam.

Ditinjau dari segi bulu terdapat 4 jenis bulu ayam cemani yaitu bulu biasa seperti bulu ayam pada biasanya, bulu walik atau jenis bulu yang tumbuh terbalik dengan bulu ayam pada biasanya, bulu lidi atau juga sering disebut rajak wesi dimana tipe bulu ini tumbuh menyerupai lidi dan yang terakhir adalah gundul atau sangat sedikit bulu yang tumbuh pada tubuh ayam cemani. Sedangkan jika ditinjau dari warna lidah terdapat 2 jenis warna yaitu abu-abu, dan hitam.

Pada umunya, para peternak ayam cemani menetaskan telur ayam cemani secara alami. Menurut Peternakan NF telur ayam cemani bisa saja ditetaskan menggunakan mesin tetas namun daya tetasnya rendah hanya sekitar 50-60\%, namun jika ditetaskan secara alami, daya tetasnya dapat mencapai $70-80 \%$. Menurut Rofii (2017) kesulitan untuk mengetahui suhu pengeraman oleh induk menyebabkan pengaturan suhu pada mesin tetas karena ayam cemani memiliki keunikan perbedaan dengan ayam kampung. Bapak Nur menggunakan penetasan secara alami maupun dengan bantuan mesin tetas berkapasitas 75 butir telur. Indukan pertama kali bertelur berumur 6-7 bulan dengan jumlah 21,83 $\pm 7,91$ butir per periode (Ismoyowati et al. 2012). Proses pengeraman ayam cemani sama seperti jenis ayam lainnya yaitu 21 hari. Setelah menetas, anak-anak ayam tersebut akan dipindah kedalam box atau kandang yang telah diberi lampu sebagai penghangat.

Fase starter dimana ayam berumur 1 - 40 hari. Fase grower dimana ayam berumur dua sampai enam bulan. Pada umur ini ayam cemani sudah mulai diseleksi untuk kepentingan ayam hias maupun sebagai persiapan untuk replacement indukan yang afkir. Pada fase ini ayam sudah dipisah sesuai jenis bulu dan warna lidah untuk keperluan seleksi dan harga jual. Fase layer dimana ayam mulai bertelur, fase ini dimulai saat ayam berumur 6-7 bulan dan diafkir setelah produksi sudah menurun pada umur sekitar 2,5 - 3 tahun.

\section{Kandang}

Kandang ayam Cemani periode grower adalah kandang battery ukuran $120 \times 60 \mathrm{~cm}^{2}$ untuk 2-3 ekor, sedangkan untuk periode produksi berupa kandang petak terkurung dengan umbaran $6 \times \mathrm{m}^{2}$ berisi 1 jantan dan 5 betina. Perbandingan jantan dan betina dalam kandang bervariasi untuk setiap peternak di Kedu, namun idealnya 1 jantan dengan 5 betina adalah perbandingan yang sering digunakan. Menurut Iskandar dan Saepudin (2004) ayam Cemani dikawinkan secara alami dengan perbandingan maksimal 1 jantan 5 betina untuk yang ditetaskan sendiri oleh induknya. Semakin banyak betina dalam satu kelompok indukan perkawinan alami akan meningkatkan mortalitas dari anak ayam (Suthar et al. 2012). Kandang pemeliharaan ayam cemani dapat dilihat pada Gambar 1 


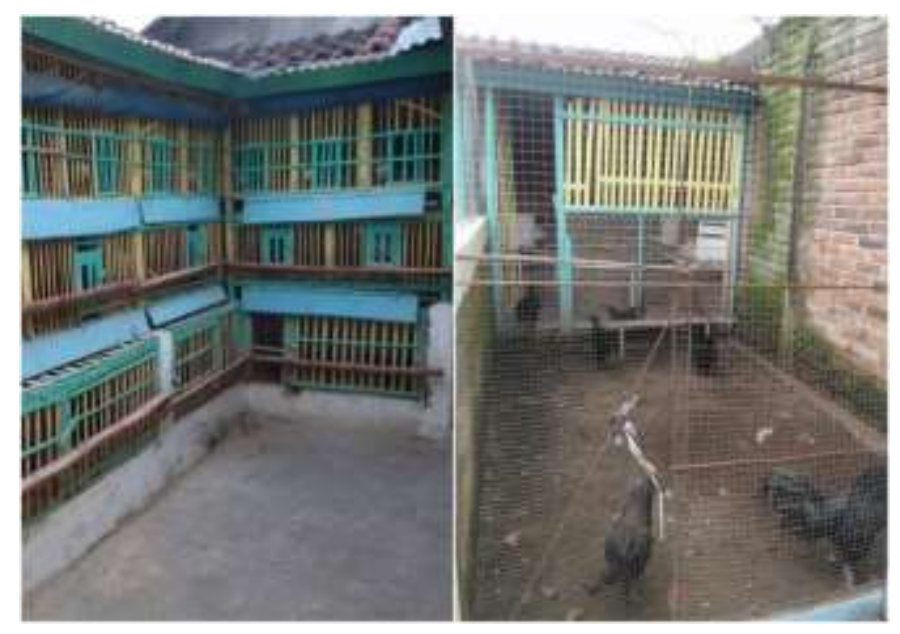

Gambar 1. Kandang Pemeliharaan Ayam Cemani

\section{Pakan}

Ayam Cemani umur 1-3 hari hanya diberi air minum yang ditambahkan dengan gula aren. Tujuan pemberian gula merah adalah untuk menambah sumber nutrisi/sumber energi untuk DOC melalui air minum agar mudah diserap dan stamina ayam kampung dapat meningkat (Aryanti et al. 2013). Pada umur 3-40 hari, ayam Cemani diberi pakan 511 dengan kandungan protein 22\% dan energi $3050 \mathrm{kkal} / \mathrm{kg}$ pemberian 25-30 g/ekor/hari. Sedangkan untuk pakan periode grower dibagi menjadi dua yaitu pada umur 41-75 hari ayam diberi pakan BR 1 dan jagung, perbandingan 1:1, dan untuk umur 76 hari- 6 bulan diberi pakan jagung giling, bekatul dan BR 1 dengan perbandingan 1:1:1 sebanyak 80 g/ekor/hari. Periode layer pada ayam cemani yaitu pada umur 6,5 bulan sampai afkir diberi pakan jagung giling, bekatul dan konsentrat petelur dengan perbandingan 3:4:3 pakan dan diberi tambahan mineral sebanyak 0,2 gram dalam $10 \mathrm{~kg}$ dengan kandungan protein 11,64\% dan EM 3598 (Rofii, 2017). Komposisi pakan dan kandungan nutrisi pada periode grower dan layer berbeda karena protein yang dibutuhkan dimanfaatkan untuk kebutuhan yang berbeda. Pemberian protein dengan kadar 17\% pada usia 14-20 minggu atau sebelum masa bertelur, dapat memberi dampak positif saat periode reproduksi (layer) (Suprijatna and Natawiharja, 2005). Namun, bila kadar protein ransum terlalu rendah akan menyebabkan pertumbuhan yang rendah pula (Bregendahl et al. 2002). Sebaliknya, bila tingkat protein ransum terlalu tinggi maka pertumbuhan akan meningkat, namun tidak sepadan dengan biaya peningkatan protein ransum (Swennen et al. 2004).

\section{Obat-obatan, Vitamin dan Vaksin}

Vaksin yang digunakan pada peternakan Bapak Nur Faizin antara lain ND dari Medivac pada minggu pertama, lalu dilanjutkan dengan Gumboro A Medivac di minggu kedua, ND Lasota by Medivac di minggu ketiga, dan ND Clone by Medivac di minggu keempat. Untuk membantu meningkatkan daya tahan tubuh, mencegah penyakit dan mengurangi stress pada Cemani, vitamin yang digunakan adalah vitachick atau vortefit yang dicampur dengan air minum untuk pencegahan penyakit di musim-musim rawan penyakit seperti musim hujan. Jika sudah terserang penyakit yang biasanya menyerang ayam cemani diantaranya Snot dan CRD diberikan obat trimicin sebagai pengobatan CRD atau prazone anti snot dan CRD. Setiap dua minggu sekali, kandang ayam cemani selalu disemprot desinfektan yang bertujuan untuk mencegah terjadinya penyebaran penyakit dan menjaga kandang agar tetap bersih. 


\section{KESIMPULAN}

Kandang yang digunakan untuk kandang ayam Cemani periode grower adalah kandang battery untuk 2-3 ekor, sedangkan untuk periode produksi berupa kandang petak terkurung dengan umbaran $6 \times 4 \mathrm{~m}^{2}$ berisi 1 jantan dan 5 betina. Ayam Cemani umur 1-3 hari hanya diberi air minum yang ditambahkan dengan gula aren. Pada umur 3-40 hari, ayam Cemani diberi pakan 511 dengan kandungan protein 22\% dan energi 3.050 $\mathrm{kkal} / \mathrm{kg}$ pemberian 25-30 g/ekor/hari. Sedangkan untuk pakan periode grower dibagi menjadi dua yaitu pada umur 41-75 hari ayam diberi pakan BR 1 dan jagung, perbandingan 1:1, dan untuk umur 76 hari- 6 bulan diberi pakan jagung giling, bekatul dan BR 1 dengan perbandingan 1:1:1 sebanyak 80 g/ekor/hari.

\section{DAFTAR PUSTAKA}

Aryanti, F., Aji, M.B., dan Budiono, N. 2013. Pengaruh pemberian air gula merah terhadap performans ayam kampung pedaging. Jurnal Sain Veteriner, 31(2), pp. 156-165.

Bregendahl, K., Sell, J. L. and Zimmerman, D. R. 2002. Effect of low-protein diets on growth performance and body composition of broiler chicks. Poultry Science, 81(8), pp. 1156-1167.

Dorshorst, B, Molin, A. M., Rubin, C. J., Johansson, A. M., Stromstedt, L., Pham, M-H., Chen, C-H., Hallböök, F., Ashwell, C. and Andersson, L. 2011. A complex genomic rearrangement involving the Endothelin 3 locus causes dermal hyperpigmentation in the chicken. PLoS Journals, 7(11), pp. 1-13.

Iskandar, S. dan Saefudin, Y. 2004. Ayam Cemani. http://balitnak.litbang.deptan.go.id. [Januari 2018].

Ismoyowati, Sukardi, dan Susanto, A. 2012. Genetic diversity of Kedu Chicken based on phenotypic characteristics and microsatellite Loci. International Journal of Poultry Science, 11(9), pp. 605-610.

Rofii, A., Saraswati, T.R., dan Yuniwarti. 2018. Phenotypic characteristic of Indonesian Native Chicken. Journal of Animal Behaviour, 6(3), pp. 56-61.

Suprijatna, E. dan Natawihardja, D. 2005. Pertumbuhan organ reproduksi ayam ras petelur dan dampaknya terhadap performans produksi telur akibat pemberian ransum dengan taraf protein berbeda saat periode pertumbuhan. Jurnal Ilmu Ternak Veteriner, 10 (4), pp. 260-267.

Suthar, M., Khan Mughal, S.A., and Azam, M. 2012. The Influence of Female:Male ratio of Fayoumi Layers on Fertility, hatchabilty of eggs and chicks livability. UDO Agricola, 12(3), pp. 644-648.

Swennen, Q., Janssens, G.P., Decuypere, E., and Buyse, J. 2004. Effects of substitution between fat and protein on feed intake and its regulatory mechanisms in broiler chickens: energy and protein metabolism and diet-induced thermogenesis. Journal of Poultry Science, 83(12), pp. 1997-2004. 